\title{
Pengaruh Model Think Talk Write Berbantuan Multimedia terhadap Keterampilan Berbicara Siswa SD
}

\author{
* Ni Pt. Diah Sawitri Pratiwi ${ }^{1}$ Md. Putra², Gst. Ngurah Sastra Agustika ${ }^{3}$ \\ 123 Program Studi Pendidikan Guru Sekolah Dasar, Universitas Pendidikan Ganesha, Singaraja, Indonesia
}

\section{A R T I C L E I N F O}

\section{Article history:}

25 December 2019

Received in revised form

01 January 2020

Accepted 25 January 2020

Available online 28

February 2020

\section{Kata Kunci:}

TTW, multimedia

keterampilan berbicara.

\section{Keywords:}

TTW, multimedia, speaking

skills drama. Penelitian ini merupakan penelitian eksperimen dengan rancangan yang digunakan adalah desain eksperimen semu. Populasi dalam penelitian ini adalah seluruh siswa Kelas V SD Gugus II Kuta Selatan yang berjumlah 402 orang. Penentuan sampel dilakukan dengan teknik random sampling. Metode pengumpulan data adalah metode non-tes menggunakan rubrik keterampilan berbicara. Rata-rata nilai siswa yang mengikuti model think talk write berbantuan multimedia, yaitu 83,56 dan siswa yang mengikuti pembelajaran konvensional, yaitu 77,05. Data yang dikumpulkan dianalisis dengan uji-t. Hasil penelitian berdasarkan uji statistik, pada taraf signifikan $5 \%(\mathrm{dk}=57$ dengan $t_{\text {hitung }}=4,65$ dan harga $t_{\text {tabel }}=2,00$ ) diperoleh keputusan bahwa $\mathrm{H}_{0}$ ditolak. Sehingga dapat disimpulkan bahwa model think talk write berbantuan multimedia memberikan pengaruh yang signifikan terhadap peningkatan keterampilan berbicara siswa SD.

\begin{abstract}
A B S T R A C T
Learning media is a part of the teaching resources that are used as intermediaries in the learning process to facilitate students' understanding of the material delivered, especially in elementary schools. There are many facts that the learning process was carried out in a teacher centered. It meant that all learning activities centered on the teacher. Teacher had not implemented innovative learning and used interesting learning media and this causes students to become bored in the classroom. Therefore, researcher try to apply the multimedia-assisted think talk write model so that the learning process becomes more innovative. The population in this research was all of fifth grade students of cluster II Kuta Selatan in academic year 2017/2018 which consisted to 402 students. The result analysis statistic at the significat level of $5 \%\left(d f=57\right.$ with $t_{\text {count }}=4.65$ and $\left.t_{\text {table }}=2.00\right)$ then $H_{0}$ there was no significant difference of speaking skill in Indonesian language subject between group of students who were taught by using think talk write model assisted with multimedia toward the students who were taught by using conventional method on drama material was rejected and the students' mean score who were followed the think talk write model assisted with multimedia was 83.56 and the students who were followed the conventional learning was 77,05. Thus, it could be concluded that there was an effect of think talk write model assisted with multimedia toward on the students'speaking skill of fifth grade students.
\end{abstract}




\section{Pendahuluan}

Kecerdasan dan kepribadian seseorang dibangun melalui wadah yang disebut dengan pendidikan. Pendidikan memiliki sebuah tujuan pembelajaran yang akan dicapai melalui berlangsungnya suatu proses antara guru dengan siswa. Berkaitan dengan hal tersebut, dirancanglah sebuah pedoman dalam kegiatan pembelajaran yang disebut dengan kurikulum. Namun seiring dengan adanya berbagai penelitian tentang dunia pendidikan yang menimbulkan perubahan-perubahan di dalam dunia pendidikan termasuk juga kurikulum. Kurikulum merupakan sebuah rencana yang menentukan arah pendidikan. Tanpa adanya kurikulum pendidikan tidak akan dapat berjalan dengan baik, efektif, dan efesien sesuai yang diharapkan. Oleh karena itu, kurikulum sangat perlu diperhatikan di masing-masing satuan pendidikan.

Sehubungan dengan hal tersebut, diperlukan strategi implementasi kurikulum di sekolah yang efektif dan efisien, terutama dalam mengoptimalkan kualitas pembelajaran. Karena bagaimana pun baiknya sebuah kurikulum (potential curriculum) efektifitasnya sangat ditentukan dalam implementasinya di sekolah, khususnya di kelas (actual curriculum).

Pada guru dan kepala sekolah, karena dua figur tersebut merupakan kunci yang menentukan serta menggerakkan berbagai komponen dan dimensi sekolah yang lain. Dengan KTSP guru dituntut untuk membuktikan profesionalismenya, mereka dituntut untuk mengembangkan rencana pelaksanaan pembelajaran (RPP) berdasarkan kompetensi dasar (KD) yang dapat digali dan dikembangkan oleh siswa. Tugas guru bukan menyuplai siswa dengan berbagai ilmu pengetahuan, tetapi guru berfungsi sebagai motivator, mediator, dan fasilitator pebelajaran(Mulyasa, 2010).

Implementasi KTSP dalam pembelajaran yang efektif dan menyenangkan menuntut guru untuk lebih sabar, penuh perhatian dan pengertian, serta mempunyai kreativitas dan penuh dedikasi untuk menumbuhkan rasa percaya diri siswa. Kondisi demikian akan menumbuhkan suasana yang kondusif dalam pembelajaran, yang akan menimbulkan rasa persahabatan antara guru dengan siswa sehingga mereka tidak canggung mengungkapkan dan mau membicarakan berbagai permasalahan yang dihadapi. Karena dengan berbicara siswa mampu menyampaikan permasalahan dan gagasan yang dimilikinya kepada orang lain. Hal itu tercapai apabila guru mampu berkomunikasi dengan seimbang dan multi arah, dengan menggunakan bahasa yang akrab, bersahabat, ramah, serta luwes dan lugas. Oleh karena itu guru harus mampu mengembangkan kompetensi dirinya sendiri sebelum membelajarkan siswa untuk mencari, menggali, dan menemukan kompetensinya(Mulyasa, 2010).

Dari uraian tersebut, kita sebagai guru harus mampu mengembangkan kreatifitas agar mampu menciptakan suasana yang kondusif serta pembelajaran yang tidak monoton dan membosankan. Selain itu, guru juga harus mampu menciptakan kelas yang mampu mengembangkan potensi siswa dan membangkitkan keaktifan siswa didalam kelas agar pembelajaran menjadi lebih menarik serta pembelajaran tidak hanya berpusat pada guru. Dengan meningkatnya keaktifan siswa di dalam kelas, siswa dapat menggali informasi dari pengalamannya sendiri serta kemampuan dan kepercaan diri siswa didalam kelas semakin meningkat. Salah satu cara untuk mewujudkan hal tersebut dengan cara menerapkan model-model pembelajaran yang menarik dan efisien. Dimana model-model pembelajaran berperan membantu guru dalam membangkitkan kembali aktifitas siswa didalam kelas dan potensipotensi siswa dapat tersalurkan dengan lebih baik. Dimasa sekarang ini sudah banyak model-model pembelajaran yang bisa diterapkan guru didalam kelas guna mengembangkan pembelajaran dan menciptakan suasana belajar yang menyenangkan dan tidak membosankan.

Penerapan model pembelajaran di dalam kelas, hendaknya guru juga menggunakan media pembelajaran guna mendukung pembelajaran tersebut. Media pembelajaran merupakan bagian dari sumber pengajaran yang digunakan sebagai perantara dalam proses pembelajaran untuk mempermudah pemahaman siswa terhadap materi yang disampaikan khususnya di sekolah dasar.

Berdasarkan pengalaman pada saat melaksanakan observasi pada tanggal 9 Januari 2018 di SD Gugus II Kuta Selatan, ditemukan fakta masalah yang muncul adalah proses pembelajaran dilakukan secara teacher centered, yaitu semua kegiatan pembelajaran berpusat kepada guru. Sekolah belum melaksanakan pembelajaran yang inovatif dan menggunakan media pembelajaran yang menarik. Sehingga proses pembelajaran menjadi kurang menarik yang menyebabkan siswa menjadi cepat bosan berada di dalam kelas. Salah satu dampaknya adalah siswa cendrung diam dan tidak bertanya pada setiap materi yang belum dipahami (Riansyah \& Sari, 2018).

Hal tersebut menyebabkan rendahnya sikap berfikir kritis, kreatif, dan sikap kerja keras siswa dalam belajar. Masalah ini secara umum terjadi di Indonesia. Wakil Sekretaris Jenderal (Wasekjen) Federasi Serikat Guru Indonesia (FSGI) Satriwan Salim dalam berita Republika yang terbit pada hari Senin 16 April 2018 mengatakan sebagian besar siswa masih berpikir level rendah. Hal ini ditunjukkan melalui sejumlah survei Pendidikan salah satunya adalah Programme for International Student Assessment (PISA). Melalui observasi juga terlihat siswa terkesan tidak memiliki motivasi untuk belajar sehingga berakibat pada hasil 
belajar siswa menjadi kurang optimal khususnya pada keterampilan berbicara pada mata pelajaran Bahasa Indonesia siswa.

Pembelajaran Bahasa Indonesia diarahkan untuk meningkatkan kemampuan siswa untuk berkomunikasi dalam Bahasa Indonesia dengan baik dan benar, baik secara lisan maupun tulis, sekaligus mengembangkan kemampuan berfikir kritis dan kreatif. Siswa dimungkinkan untuk memperoleh kemampuan berbahasanya dari bertanya, menjawab, menyanggah, dan beradu argumen dengan orang lain. Kegiatan berbahasa Indonesia mencakup kegiatan produktif dan reseptif yang dijabarkan kedalam empat aspek berbahasa, yaitu mendengarkan, berbicara, membaca, dan menulis. Kemampuan berbahasa yang reseptif pada hakikatnya merupakan kemampuan untuk memahami bahasa yang dituturkan oleh pihak lain. Pemahaman terhadap bahasa yang dituturkan oleh pihak lain tersebut dapat melalui sarana bunyi atau sarana lisan.

Salah satu keterampilan yang diharapkan dimiliki oleh siswa dari sekolah dasar ini adalah keterampilan berbahasa yang baik, karena bahasa merupakan modal terpenting bagi manusia. Pengajaran Bahasa Indonesia memiliki empat aspek yang harus dikuasai oleh siswa, yaitu mendengarkan, berbicara, membaca, dan menulis. Keempat aspek tersebut memiliki keterkaitan satu dengan lainnya. Sebagai makhluk sosial, manusia berinteraksi, berkomunikasi dengan manusia lain dengan menggunakan bahasa sebagai media, baik berkomunikasi menggunakan bahasa lisan, juga berkomunikasi menggunakan bahasa tulis(Susanto, 2013).

Berbicara adalah keterampilan bahasa lisan yang bersifat produktif, baik yang interaktif, semi interaktif, dan noninteraktif. Berbicara adalah aktivitas berbahasa kedua yang dilakukan manusia dalam kehidupan berbahasa, yaitu setelah aktivitas mendengarkan. Berdasarkan bunyi-bunyian (bahasa) yang didengar itulah kemudian manusia belajar mengucapkan dan akhirnya mampu untuk berbicara. Untuk dapat berbicara dalam suatu bahasa secara baik, pembicara harus menguasai lafal, struktur, dan kosa kata yang akan disampaikan. Di samping itu, diperlukan juga penguasaan masalah atau gagasan yang akan disampaikan serta kemampuan memahami bahasa lawan bicara.

Sebagai falisitator dalam pembelajaran, guru sangat berperan menentukan bagaimana siswa sebagai subjek belajar melakukan aktivitas untuk meningkatkan pengetahuannya. Guru harus senantiasa menyajikan kegiatan pembelajaran yang berpusat pada siswa (student oriented). Guru menyesuaikan keseluruhan mata pelajaran dengan kebutuhan dan minat siswa untuk berkembang menjadi pribadi yang mandiri, kreatif dan inovatif. Salah satunya yaitu dengan menerapkan model pembelajaran think talk write berbantuan multimedia. Think Talk Write adalah strategi yang memfasilitasi siswa latihan berbahasa secara lisan dan menulis bahasa tersebut dengan lancar. Model Think Talk Write mendorong siswa untuk berfikir, berbicara, dan kemudian menulis suatu topik tertentu. Dengan menggunakan model ini, siswa dilatih untuk memiliki kemampuan yang baik dalam berpikir, berbicara, dan kemudian menuliskan suatu topik tertentu. Model pembelajaran ini mengharuskan banyaknya terjadi interaksi antar peserta didik dan tidak terpusat pada guru, sehingga pembelajaran aktif menjadi menarik dan menyenangkan (Savitri, Emidar, \& Rasyid, 2018). Hasil penelitian menujukkan bahwa pembelajaran kooperatif tipe Think Talk Write berpengaruh terhadap keaktifan siswa dan hasil belajar secara signifikan (Rizal, 2018), (Muhsin, Sukib, \& Laksmiwati, 2019).

Pelaksanaan pembelajaran di dalam kelas, guru berkewajiban memvariasikan pembelajaran dan tidak selalu berpatokan dan berpedoman hanya dengan buku saja. Saat ini sudah banyak teknologi yang bisa digunakan untuk mendukung jalannya proses pembelajaran di dalam kelas untuk merangsang dan menarik minat siswa untuk belajar dan tidak mudah merasa bosan ketika di dalam kelas. Salah satu media pembelajaran yang dapat digunakan yaitu multimedia. Multimedia merupakan perpaduan berbagai bentuk elemen informasi yang diguanakan sebagai sarana menyampaikan tujuan tertentu. Elemen informasi yang dimaksud tersebut antara lain teks, grafik, gambar, foto, animasi, audio, dan video. Kegiatan belajar di dalam kelas dengan memanfaatkan teknologi seperti multimedia sangatlah cocok diterapkan dalam upaya meningkatkan keterampilan berbicara siswa khususnya pada mata pelajaran Bahasa Indonesia.

Think Talk Write (TTW) adalah strategi yang memfasilitasi siswa latihan berbahasa secara lisan dan menulis bahasa tersebut dengan lancar. Strategi Think Talk Write (TTW) mendorong siswa untuk berfikir, berbicara, dan kemudian menulis suatu topik tertentu. Strategi ini digunakan untuk mengembangkan tulisan dengan lancar dan melatih bahasa sebelum dituliskan. Strategi Think Talk Write (TTW) memberikan siswa ruang untuk mempengaruhi dan memanipulasi ide-ide sebelum menuangkannya dalam bentuk tulisan(Huda, 2013). Multimedia merupakan perpaduan berbagai bentuk elemen informasi yang diguanakan sebagai sarana menyampaikan tujuan tertentu. Elemen informasi yang dimaksud tersebut antara lain teks, grafik, gambar, foto, animasi, audio, dan video (Wati, 2016). Hasil-hasil penelitian menunjukkan bahwa multimedia memiliki pengaruh yang positif terhadap hasil belajar siswa 
baik kognitif maupun keterampilan (Khaeruman, Azizah, \& Nurhidayati, 2018) (Gufron, Darwan, \& Winarso, 2018).

Model pembelajaran think talk write berbantuan multimedia merupakan salah satu bentuk model pembelajaran yang berpusat pada partisipasi dan aktivitas siswa untuk mencari sendiri materi atau segala sesuatu mengenai materi pelajaran yang akan dipelajari. Informasi tersebut bisa didapat dari bahan yang tersedia, misalnya dari buku pelajaran, perpustakaan, atau dari internet dengan referensi yang bisa dipertanggung jawabkan. Model TTW mempengaruhi sikap positif siswa (Sumbawati \& Artika, 2019).

Berdasarkan uraian tersebut, pemilihan model maupun media dalam proses pembelajaran sangatlah penting dilakukan oleh guru untuk membelajarkan siswa di dalam kelas khususnya dalam meningkatkan keterampilan berbicara pada mata pelajaran Bahasa Indonesia siswa. Untuk mengetahui seberapa jauh model maupun multimedia dapat berpengaruh terhadap keterampilan berbicara siswa, maka dilakukan penelitian yang berjudul "Pengaruh Model Think Talk Write berbantuan Mutimedia terhadap Keterampilan Berbicara pada Mata Pelajaran Bahasa Indonesia Siswa Kelas V SD Gugus II Kuta Selatan Tahun Ajaran 2017/2018".

\section{Metode}

Rancangan penelitian ini termasuk dalam bentuk penelitian eksperimen semu (Quasi Experiment). Desain ini memiliki kelompok kontrol, tetapi tidak dapat berfungsi sepenuhnya untuk mengontrol variabel-variabel luar yang mempengaruhi pelaksanaan eksperimen" (Sugiyono, 2015). Bentuk desain eksperimen kuasi yang digunakan adalah " Desain Penelitian Nonequivalent Posttest Only Control Group Design". Populasi dari penelitian ini adalah seluruh siswa kelas V (lima) SD Gugus II Kuta Selatan Tahun 2018, yang terdiri dari 12 kelas dalam 6 sekolah dasar. Jumlah populasi dari penelitian ini adalah 402 siswa. Teknik pengambilan sampel pada penelitian ini adalah Random Sampling yang dirandom kelasnya, sehingga setiap kelas mendapatkan peluang yang sama untuk menjadi sampel penelitian. Pemilihan sampel penelitian ini tidak dilakukannya pengacakan individu melainkan hanya pengacakan kelas. Karena tidak bisa mengubah kelas yang telah terbentuk sebelumnya. Kelas dipilih sebagaimana telah terbentuk tanpa campur tangan peneliti dan tidak dilakukannya pengacakan individu, kemungkinan pengaruhpengaruh dari keadaan siswa mengetahui dirinya dilibatkan dalam eksperimen dapat dikurangi sehingga penelitian ini benar-benar menggambarkan pengaruh perlakuan Sampel dalam penelitian ini adalah siswa kelas V/a SD N0. 6 Benoa berjumlah 26 siswa sebagai kelompok eksperimen dengan diberi perlakuan berupa model think talk write berbantuan multimedia dan siswa kelas V/c SD No. 2 Tanjung Benoa berjumlah 33 siswa sebagai kelompok kontrol dengan diberi perlakuan berupa pembelajaran konvensional.

Variabel bebas bebas dari penelitian ini adalah model think talk write berbantuan multimedia. Sedangkan variable terikat pada penelitian ini adalah keterampilan berbicara pada mata pelajaran Bahasa Indonesia.

Data yang didapatkan dalam penelitian ini dengan cara melakukan posttest yang dikumpulkan dengan metode non-tes menggunakan rubrik sebagai instrumen setelah perlakuan yang diberikan kepada kelompok eksperimen dan kelompok kontrol dalam pembelajaran. Sebelum digunakan, instrumen tersebut terlebih dahulu divalidasi dengan cara dikonsultasikan pada ahli. Uji instrumen dilakukan untuk mendapatkan tes yang standar (baku). Akan dilakukan uji validitas isi untuk instrumen pada penelitian ini. Validasi isi dilakukan dengan membandingkan isi instrumen dengan kurikulum dan materi pelajaran. "Validitas isi merujuk pada sejauh mana instrumen tersebut menggambarkan atau mencerminkan isi yang dikehendaki. Teknik yang digunakan untuk menganalisis keterampilan berbicara pada mata pelajaran Bahasa Indonesia dalam penelitian ini adalah dengan menggunakan analisis statistik yaitu uji-t. Sebelum dilaksanakannya uji prasyarat yang meliputi uji normalitas dan uji homogenitas varians.

\section{Hasil dan pembahasan}

Adapun hasil analisis data kelompok eksperimen dan kelompok kontrol disajikan pada tabel 1.

Tabel 1. Deskripsi Kompetensi Pengetahuan IPA Kelompok Eksperimen dan Kontrol

\begin{tabular}{lcc}
\hline \multicolumn{1}{c}{ Statistik Deskriptif } & $\begin{array}{c}\text { Kelompok } \\
\text { eksperimen }\end{array}$ & Kelompok Kontrol \\
\hline N & 26 & 33 \\
Nilai Minimum & 65 & 70 \\
Nilai Maksimum & 95 & 85
\end{tabular}




\begin{tabular}{lcc} 
Mean & 83,56 & 77,05 \\
Modus & 85 & 75 \\
Median & 85 & 75 \\
Variansi & 38,36 & 20,94 \\
Standar Deviasi & 6,19 & 4,58 \\
\hline
\end{tabular}

Data yang diperoleh dari penelitian ini kemudian dianalisis menggunakan statistik melalui tahapan meliputi uji normalitas, uji homogentitas, dan uji hipotesis Maka harus dilakukan beberapa uji prasyarat terhadap sebaran data yang meliputi uji normalitas dan uji homogenitas varians. Hasil uji normalitas kelompok eksperimen, diperoleh Chi Kuadrat hitung $\left(x^{2}\right.$ hitung $\left.=7,97\right)$ kemudian nilai tersebut dibandingkan dengan Chi Kuadrat tabel $\left(x^{2}{ }_{\text {tabel }}=11,07\right)$. Hal ini menunjukkan bahwa $x^{2}$ hitung $\leq x^{2}$ tabel berarti data keterampilan berbicara pada mata pelajaran Bahasa Indonesia kelompok eksperimen berdistribusi normal. Hasil uji normalitas kelompok kontrol, diperoleh Chi Kuadrat hitung $\left(x^{2}{ }_{\text {hitung }}=2,23\right)$ kemudian nilai tersebut dibandingkan dengan Chi Kuadrat tabel $\left(x^{2}\right.$ tabel= 11,07). Hal ini menunjukkan bahwa $x^{2}{ }_{\text {hitung }} \leq x^{2}$ tabel berarti data keterampilan berbicara pada mata pelajaran Bahasa Indonesia kelompok kontrol berdistribusi normal. Homogenitas varians data keterampilan berbicara pada mata pelajaran Bahasa Indonesia dianalisis dengan uji $\mathrm{F}$ Dari hasil analisis, diperoleh $\mathrm{F}_{\text {hitung }}=1,83$ dan $\mathrm{F}_{\text {tabel }}=$ 1,86. Hal ini berarti $F_{\text {hitung }}<\mathrm{F}_{\text {tabel }}$, sehingga data kedua kelompok memiliki varians yang homogen. Hipotesis yang diuji dalam penelitian ini adalah tidak terdapat perbedaan yang signifikan keterampilan berbicara pada mata pelajaran Bahasa Indonesia antara siswa kelas V di Gugus II Kuta Selatan tahun ajaran 2017/2018 yang mengikuti pembelajaran menggunakan model think talk write berbantuan multimedia dan siswa yang mengikuti pembelajaran konvensional pada materi drama. Kriterian pengujian adalah $\mathrm{H}_{0}$ ditolak jika $t_{\text {hitung }}>\mathrm{t}_{\text {tabel }}$ dimana $\mathrm{t}_{\text {tabel }}$ diperoleh dari tabel distribusi $\mathrm{t}$ pada taraf signifikan 5\% dengan dk (n1 + n2)-2. Rangkuman hasil analisis uji-t ditunjukkan pada Tabel 2.

Tabel 2. Rangkuman Hasil Uji-t

\begin{tabular}{ccccc}
\hline Kelompok & $\mathbf{N}$ & $\mathbf{D k}$ & $\mathbf{t}_{\text {hitung }}$ & $\mathbf{t}_{\text {tabel }}$ \\
\hline Eksperimen & 26 & 57 & 4,65 & 2,00 \\
Kontrol & 33 & & & \\
\hline
\end{tabular}

Berdasarkan kriteria pengujian karena $t_{\text {hitung }}>t_{\text {tabel }}$ maka $H_{o}$ ditolak dan $H_{a}$ diterima. Artinya terdapat perbedaan yang signifikan keterampilan berbicara pada mata pelajaran Bahasa Indonesia antara kelompok siswa yang dibelajarkan melalui model think talk write berbantuan multimedia dengan kelompok siswa yang dibelajarkan melalui pembelajaran konvensional pada kelas V SD Gugus II Kuta Selatan tahun ajaran 2017/2018.

Berdasarkan uji hipotesis diperoleh $t_{\text {hitnung }}=4,65$ sedangkan pada taraf signifikansi $5 \%$ dan $\mathrm{dk}=$ 57 diperoleh nilai $t_{\text {tabel }}=2,00$ sehingga $t_{\text {hitnung }}=4,65>t_{\text {tabel }}=2,000$. Dengan demikian, hipotesis nol $\left(H_{0}\right)$ ditolak. Hal ini berarti terdapat perbedaan yang signifikan keterampilan berbicara pada mata pelajaran Bahasa Indonesia antara kelompok siswa yang dibelajarkan melalui model think talk write berbantuan multimedia dengan kelompok siswa yang dibelajarkan melalui pembelajaran konvensional pada kelas $\mathrm{V}$ SD Gugus II Kuta Selatan tahun ajaran 2017/2018 pada materi drama. Perolehan hasil perhitungan analisis data yang dilakukan menunjukkan bahwa nilai rerata siswa yang mengikuti pembelajaran menggunakan model think talk write berbantuan multimedia $(\bar{X}=83,56)$ dan siswa yang mengikuti pembelajaran konvensional ( $\bar{X}=77,05$ ) memiliki perbedaan sebesar 7,35. Dengan demikian, terdapat pengaruh yang signifikan pada keterampilan berbicara pada mata pelajaran Bahasa Indonesia siswa kelas V SD Gugus II Kuta Selatan tahun ajaran 2017/2018 kelompok siswa yang dibelajarkan melalui model think talk write berbantuan multimedia dengan kelompok siswa yang dibelajarkan melalui pembelajaran konvensional pada materi drama.

Berdasarkan hasil temuan tersebut, setelah diberikan perlakuan berupa pembelajaran dengan menggunakan model think talk write berbantuan multimedia dan mengikuti pembelajaran menggunakan model pembelajaran konvensional diperoleh keterampilan yang berbeda. Hal ini dapat dilihat juga dari nilai rata-rata siswa yang mengikuti pembelajaran menggunakan model think talk write berbantuan multimedia lebih tinggi dibandingkan dengan rata-rata siswa yangmengikuti pembelajaran konvensional. Perbedaan keterampilan dengan perolehan nilai rata-rata yang lebih tinggi pada kelompok eksperimen dibandingkan kelompok kontrol disebabkan oleh perlakuan berupa model think talk write berbantuan 
multimedia dalam keterampilan berbicara pada mata pelajaran Bahasa Indonesia diberikan pada kelompok eksperimen.

Pada kelompok eksperimen, kegiatan pembelajaran dalam muatan materi drama pada mata pelajaaran Bahasa Indonesia menggunakan model think talk write berbantuan multimedia berjalan dengan optimal dan kondusif. Hal ini terlihat dari adanya peningkatan keaktifan siswa di dalam kelas. Siswa mulai mampu berpikir kritis, kreatif dan siswa mampu menunjukkan sikap kerja keras dalam pembelajaran. Interaksi antara guru dan siswa berjalan secara dua arah. Hal ini tidak telepas dari desain pembelajaran yang diterapkan guru. Guru merencanakan, melaksanakan, mengevaluasi, dan memberikan variasi model pembelajaran TTW ternyata membuat siswa tidak cepat bosan dalam belajar (Putra, Adurahman, \& Nursaid, 2017). Model ini juga mendorong siswa untuk berpartisipasi dalam proses belajar mengajar (Fitri, Syahrul R, \& Catri Tamsin, 2016).

Siswa mampu menyampaikan hal-hal yang berkaitan dengan pembelajaran menggunakan bahasanya sendiri. Hal ini sejalan dengan penerapan model Think Talk Write (TTW) yang memfasilitasi siswa latihan berbahasa secara lisan dan menulis bahasa tersebut dengan lancar (Huda, 2013).Hasil yang sama juga diperoleh oleh (Fadilah, 2016) yang menerapkan strategi Think Talk Write dalam meningkatkan kemampuan berbahasa anak tuna rungu. Dalam penelitiannya model Think Talk Write mampu mengoptimalkan artikulasi yang dimiliki oleh anak tuna rungu. Multimedia pembelajaran dapat memotivasi pikiran, perasaan, perhatian, dan kemauan belajar siswa sehingga secara sengaja proses belajar terjadi, bertujuan, dan terkendali (Wati, 2016). Jadi model think talk write berbantuan multimedia merupakan suatu inovasi pembelajaran yang menekankan siswa dalam latihan berbahasa secara lisan dan menulis bahasa dengan lancar dan multimedia sebagai media pembelajaran yang mempuni. Selama kegiatan pembelajaran siswa dapat membangun pengetahuannya dengan cara berfikir, berbicara, dan kemudian menulis suatu topik tertentu sehingga pengetahuan yang mereka peroleh tidak hanya persifat hafalan melainkan sebuah pemahaman nyata. Selama kegiatan pembelajaran siswa lebih aktif karena kegiatan pembelajaran menggunakan model think talk write berbantuan multimedia menciptakan lingkungan belajar yang menarik dengan multimedia sebagai media pembelajaran dan memberikan kebebasan siswa untuk mengemukakan pendapat dan mengasah keterampilan berbahasanya terutama dalam keterampilan berbicara.

Think Talk Write (TTW) adalah strategi yang memfasilitasi siswa latihan berbahasa secara lisan dan menulis bahasa tersebut dengan lancar (Huda, 2013). Model TTW secara umum juga berpengaruh positif terhadap hasil belajar siswa (Kartijono \& Rahayuningsih, 2017), (Hardianti, Kodirun, \& Lambertus, 2018). Multimedia merupakan perpaduan berbagai bentuk elemen informasi yang diguanakan sebagai sarana menyampaikan tujuan tertentu. Elemen informasi yang dimaksud tersebut antara lain teks, grafik, gambar, foto, animasi, audio, dan video (Wati, 2016). Model Think Talk Write berbantuan multimedia merupakan pembelajaran yang memfasilitasi siswa latihan berbahasa secara lisan dan menulis yang dibantu dengan beberapa gabungan dari berbagai media teks, gambar, video dan animasi yang merupakan suatu kesatuan yang secara bersama-sama menampilkan informasi, pesan, atau pelajaran yang dapat memfasilitasi komunikasi dalam pembelajaran guna menyampaikan pesan berupa pengetahuan, keterampilan, dan sikap kepada siswa. Hasil penelitian yang diperoleh bahwa nilai $t_{\text {hitung }}=4,65>t_{\text {tabel }}=$ 2,00 , sehingga Ho atau hipotesis nol yang berbunyi tidak terdapat perbedaan yang signifikan keterampilan berbicara pada mata pelajaran Bahasa Indonesia antara kelompok siswa yang dibelajarkan melalui model think talk write berbantuan multimedia dengan kelompok siswa yang dibelajarkan melalui pembelajaran konvensional pada kelas V SD Gugus II Kuta Selatan tahun ajaran 2017/2018 ditolak dan menerima $\mathrm{H}_{a}$ yang berbunyi terdapat perbedaan yang signifikan keterampilan berbicara pada mata pelajaran Bahasa Indonesia antara kelompok siswa yang dibelajarkan melalui model think talk write berbantuan multimedia dengan kelompok siswa yang dibelajarkan melalui pembelajaran konvensional pada kelas V SD Gugus II Kuta Selatan tahun ajaran 2017/2018. Hal ini sejalan dengan penelitian lainnya yang menemukan bahwa Model pembelajaran kooperatif tipe think, talk, write (TTW) yang dipadu dengan media berpengaruh terhadap hasil belajar (Maharlika, Santosa, \& Prayitno, 2018). Model ini juga dapat meningkatkan aktivitas siswa dan keterampilan siswa (Wibowo \& Roysa, 2018).

\section{Simpulan dan saran}

Berdasarkan hasil penelitian dan pembahasan dapat dikemukakan simpulan sebagai berikut. Nilai rata-rata keterampilan berbicara pada mata pelajaran Bahasa Indonesia siswa yang dibelajarkan melalui model think talk write berbantuan multimedia lebih tinggi dibanding dengan kelompok siswa yang dibelajarkan melalui pembelajaran konvensional. Kelompok siswa yang dibelajarkan melalui model think talk write berbantuan multimedia memiliki nilai rata-rata sebesar 83,65 dan kelompok siswa yang dibelajarkan melalui model pembelajaran konvensional memiliki nilai rata-rata sebesar 77,05 . Dari hasil 
uji hipotesis yang telah dilakukan dengan berdasarkan taraf signifikasi $5 \%$ dengan $\mathrm{dk}=57$ diperoleh $\mathrm{t}_{\text {tabel }}=$ 2,00 dan setelah dilakukan analisis diperoleh $t_{\text {hitung }}=4,65$. Hal ini berarti terdapat perbedaan yang signifikan keterampilan berbicara pada mata pelajaran Bahasa Indonesia antara kelompok siswa yang dibelajarkan melalui model think talk write berbantuan multimedia dengan kelompok siswa yang dibelajarkan melalui pembelajaran konvensional pada kelas V SD Gugus II Kuta Selatan tahun ajaran 2017/2018 pada materi drama. Dengan demikian, pembelajaran menggunakan model think talk write berbantuan multimedia pada penelitian ini memiliki keunggulan yakni dapat membuat siswa lebih aktif dalam pembelajaran dan meningkatkan kemampuan berpikir siswa dengan memberikan pengalaman yang berkesan bagi siswa didukung oleh peran guru dalam pemberian materi, tidak adanya diskriminasi, serta pengakuan atas usaha yang dilakukan.

Dari hasil penelitian yang telah dilakukan, dalam pembelajaran di kelas guru harus mampu memvariasikan pembelajaran guna meningkatkan minat belajar siswa. Salah satunya dengan pemilihan model pembelajaran yang tepat dan didukung oleh media yang tepat dapat berpengaruh terhadap keterampilan berbicara pada mata pelajaran Bahasa Indonesia siswa. Penelitian ini membuktikan bahwa model think talk write berbantuan multimedia baik diterapkan dalam proses pembelajaran sebagai upaya meningkatkan keterampilan berbicara pada mata pelajaran Bahasa Indonesia siswa.

Berdasarkan hasil penelitian ini, maka dapat disajikan beberapa saran guna peningkatan kualitas pembelajaran Bahasa Indonesia di sekolah dasar antara lain sebagai berikut. Kepada guru agar lebih kreatif dan inovatif untuk meningkatkan minat belajar serta memberikan kesempatan yang lebih besar kepada siswa untuk berpartisipasi dalam pembelajaran di dalam kelas dengan menggunakan model think talk write berbantuan multimedia sehingga tercipta pembelajaran yang menarik dan bermakna bagi siswa. Kepada kepala sekolah agar dapat menggunakan hasil penelitian ini sebagai pendukung sumber belajar guru dalam meningkatkan kualitas pembelajaran dengan menciptakan pembelajaran yang menarik di sekolah sehingga sekolah mampu menghasilkan siswa yang memiliki output berkualitas. Kepada peneliti lain disarankan agar hasil penelitian ini digunakan sebagai referensi untuk melaksanakan penelitian selanjutnya atau menemukan inovasi kegiatan pembelajaran lainnya yang bermakna dan berdampak positif bagi siswa.

\section{Daftar Rujukan}

Fadilah, N. (2016). Penerapan Strategi Think Talk Write dalam Meningatkan Kemampuan Berbahasa Anak Tunarungu. JASSI_anakku, 18(2), 13-19.

Fitri, Y., Syahrul R, \& Catri Tamsin, A. (2016). Pengaruh model pembelajaran kooperatif tipe think talk write berbantuan media gambar terhadap keterampilan menulis karangan argumentasi siswa kelas X SMA Negeri 5 Padang. Jurnal Pendidikan Bahasa dan Sastra Indonesia, 5(2), 548-554.

Gufron, A., Darwan, \& Winarso, W. (2018). Penggunaan bahan ajar berbasis multimedia interaktif terhadap hasil belajar matematika siswa. Jurnal Inovasi Pendidikan dan Pembelajaran Matematika, $4(2), 77-88$.

Huda, M. (2013). Model-Model Pengajaran dan Pembelajaran Isu-isu Metodis dan Paradigmatis. Yogyakarta: Pustaka Belajar.

Hardianti, Kodirun, \& Lambertus. (2018). Pengaruh model pembelajaran think talk write (TTW) terhadap peningkatan kemampuan menulis matematis siswa SMA ditinjau dari self efficacy. Jurnal Pendidikan Matematika, 9(1), 63-72.

Kartijono, K. N., \& Rahayuningsih, M. (2017). Pengaruh pembelajaran model think talk write materi ekosistem terhadap hasil belajar siswa. Lembaran Ilmu Kependidikan, 46(2), 35-40.

Khaeruman, Azizah, R., \& Nurhidayati , S. (2018). Pengaruh multimedia interaktif terhadap keterampilan generik sains dan pemahaman konsep elektrokimia siswa. Jurnal Ilmu Sosial dan Pendidikan, 2(1), 239-337.

Maharlika, A. R., Santosa, S., \& Prayitno, B. (2018). Pengaruh model pembelajaran kooperatif tipe think, talk, write (TTW) yang dipadu dengan media buku komik biologi terhadap hasil belajar siswa SMA. Proceeding Biology Education Conference, (pp. 309-316).

Muhsin, L. B., Sukib, \& Laksmiwati, D. (2019). Pengaruh model pembelajaran think talk write (ttw) berpikir bicara menulis terhadap hasil belajar siswa pada mata pelajaran kimia materi koloid. Chemistry Education Practice, 2(2), 36-42. 
Mulyasa. (2010). Implementasi Kurikulum Tingkat Satuan Pendidikan. Jakarta: Bumi Aksara.

Putra, A. D., Adurahman, \& Nursaid. (2017). Pengaruh model pembelajaran kooperatif tipe think talk write berbantuan media gambar berseri terhadap keterampilan menulis teks cerpen siswa kelas Vii Smp Negeri 8 Padang. Jurnal Pendidikan Bahasa dan Sastra Indonesia, 6(1), 1-9.

Riansyah, F., \& Sari, A. (2018). Pengaruh penerapan pembelajaran kooperatif tipe think talk write (TTW) terhadap kemampuan pemecahan masalah matematika ditinjau dari kemampuan awal matematika. Journal for Research in Mathematics Learning, 1(2), 119-126.

Rizal, M. S. (2018). Pengaruh model pembelajaran kooperatif tipe think talk write (ttw) terhadap keaktifan dan hasil belajar IPS kelas IV SDM 020 Kuok. Jurnal Kajian Pendidikan dan Hasil Penelitian, 4(2), 741-751.

Savitri, S., Emidar, \& Rasyid, Y. (2018). Pengaruh model pembelajaran kooperatif tipe think talk write terhadap keterampilan menulis teks eksposisi siswa kelas VII mtss diniyah pandai sikek. Jurnal Pendidikan Bahasa dan Sastra Indonesia, 7(3), 355-361.

Sumbawati, M. S., \& Artika, H. N. (2019). Penerapan metode pembelajaran kooperatif tipe think talk write berbantuan edublogs. Journal of Vocational and Technical Education, 1(2), 27-36.

Wibowo, S. A., \& Roysa, M. (2018). Efektivitas penggunaan model think talk write berbantuan media komik strip dalam peningkatan keterampilan menulis dialog sederhana siswa kelas V SD 1 Tritis. Jurnal Kredo, 1(2), 148-161.

Wati, E. R. (2016). Ragam Media Pembelajaran. Yogyakarta: Kata Pena.

Sugiyono, M. (2015). Metode Penelitian Pendidikan. Bandung: Alfabeta.

Susanto, A. (2013). Teori Belajar dan Pembelajaran di Sekolah Dasar. Jakarta: Prenadamedia Group. 